\title{
Analysis of reporting of systematic reviews in physical therapy published in Portuguese
}

\author{
Análise da apresentação textual de revisões sistemáticas em fisioterapia \\ publicadas no idioma português
}

Rosimeire S. Padula', Raquel S. Pires', Sandra R. Alouche', Luciana D. Chiavegato', Alexandre D. Lopes', Leonardo O. P. Costa',2

\begin{abstract}
Background: Systematic reviews are considered the best design to synthesize all existing information of a given research topic. To date, there is no study that investigated the quality of reporting of systematic reviews relevant to physical therapy published in Portuguese. Objective: To analyse the quality of reporting of systematic reviews in the field of physical therapy published in Portuguese by using the PRISMA (Preferred Reporting Items for Systematic Reviews and Meta-Analysis) checklist. Method: All systematic reviews published in Portuguese that were indexed on PEDro database up to August 2011 were included. The quality of reporting of the eligible papers was analysed by using the PRISMA checklist. Each quality assessment was performed by two independent reviewers with arbitration of a third reviewer if necessary. Results: A total of 37 systematic reviews were identified. These studies were published between 2003 and 2010. Less than 30\% of the PRISMA checklist items were satisfied, being most of the items related to the introduction and discussion sections. No improvements over time were observed. Conclusions: Most of the studies did not satisfy the items from the PRISMA Checklist. It seems that most of authors did not know the existence of this checklist. The implementation of reporting statements such as the PRISMA statement by Portuguese-written journals is likely to help authors to write their systematic reviews in a more transparent and clear way.
\end{abstract}

Keywords: systematic review; editorial policies; physical therapy.

\section{Resumo}

Contextualização: As revisões sistemáticas são consideradas a melhor forma de sintetizar toda a informação existente sobre um determinado tópico, porém não se conhece, até o momento, a qualidade da apresentação textual das revisões sistemáticas em fisioterapia publicadas no idioma português. Objetivo: Analisar a apresentação textual de revisões sistemáticas em fisioterapia publicadas no idioma português utilizando as recomendações PRISMA (Preferred Reporting Items for Systematic Reviews and Meta-Analyses). Método: Foram analisadas todas as revisões sistemáticas apresentadas na base de dados PEDro até o mês de agosto de 2011. Para a análise da descrição textual foi utilizada a lista de verificação PRISMA. Cada revisão foi avaliada por pares de revisores independentes e, em caso de discordância entre os pares, um terceiro avaliador fez a arbitragem final. Resultados: Foram identificadas 37 revisões sistemáticas que foram publicadas entre os anos de 2003 e 2010. Menos de 30\% dos itens da lista de verificação PRISMA foram descritos pelos autores, sendo que a maioria dos itens satisfeitos se refere às seções de introdução e discussão. Observou-se que não houve um aumento na adesão aos itens recomendados para a apresentação textual com o passar do tempo. Conclusões: A adesão aos critérios preconizados pela lista de verificação da PRISMA é baixa para revisões sistemáticas publicadas no idioma português, o que pode ser reflexo do desconhecimento da existência de tais recomendações. A implementação de recomendações aos autores pelos periódicos nacionais poderá auxiliar os autores na redação de seus artigos, melhorando a clareza com que reportam seus estudos.

Palavras-chave: revisão sistemática; políticas editoriais; fisioterapia.

Received: 09/13/2011 - Revised: 11/24/2011 - Accepted: 01/16/2012

${ }^{1}$ Masters in Physical Therapy, Universidade Cidade de São Paulo (UNICID), São Paulo, SP, Brazil 


\section{Introduction $: \because$.}

Physical therapists that aim to be updated on the effectiveness of interventions commonly deal with a challenge: how to manage the large volume of scientific articles? Currently, there are nearly 20 thousand studies related to the efficacy of physical therapy interventions ${ }^{1}$, being about 1,000 clinical practice guidelines, 3,000 are systematic reviews and 16,000 are randomized controlled trials. If the current rhythm of publications in the field of physical therapy is constant, there will be a duplication of the whole content published in three years ${ }^{2,3}$.

Physical therapists commonly need to search for high-quality scientific evidence to support their clinical decisions. This evidence should be searched in randomized controlled trials or in systematic reviews, since these experimental designs are the most adequate to measure the effects of a given intervention $^{4}$. Due to the high volume of randomized controlled trials published, probably the most adequate source of information for any health-care professional are systematic reviews of randomized controlled trials.

Systematic reviews are considered the best method to synthesize all the existent information about a certain topic ${ }^{4}$. A high-quality systematic review must always summarize all evidence available, taking into account the methodological quality of each study. The results from the systematic reviews must, therefore, consider either the sample size as well as the methodological quality of each individual trial using, whenever possible, statistical methods such as meta-analysis ${ }^{5}$. Three characteristics are essential for a high-quality systematic review: 1 ) to synthesize all evidence available; 2) to evaluate the methodological quality of each individual study; 3 ) to summarize the results from the eligible studies adequately (either by meta-analysis or descriptively). If the systematic review does not have such characteristics, caution is needed to interpret the results, since they could not represent the real evidence of the intervention reviewed.

To guarantee that the readers will be able to adequately judge the information of a systematic review, it is necessary that systematic reviews are clearly presented ${ }^{6}$. Only reviews with adequate reporting of methods, results and conclusions allow the adequate critical appraisal of the study and consequently, allow if the information is reliable enough to be used to support clinical practice as well as research.

A group of methodologists aimed to create guidelines on how to report a systematic review in a clear way developed in 1999 a checklist of essential items to be included in any systematic review. This guideline is known as the QUORUM statement (Quality of Reporting of Meta-analyses). The
QUORUM $^{7}$ recommendations had been updated in 2009 and is now named as PRISMA Statement ${ }^{8,9}$ (Preferred Reporting Items for Systematic Reviews and Meta-Analysis). The PRISMA statement includes a checklist of 27 items properly described and exemplified and a four-phase flow diagram ${ }^{8,9}$. The 27 items guide the authors of systematic reviews on the information that must be clearly described in the manuscript, including specific instructions for title, abstract, methods, results and financial support (Appendix 1). Among the items from the PRISMA Statement, there are the international registration of systematic review, the summary of the major findings of the review and the description of the limitations and results of the articles. These items reduce redundancy, increase transparency and facilitate the interpretation of the results of systematic reviews ${ }^{10}$.

The PRISMA Statement was used to evaluate the characteristics of Chinese traditional medicine systematic reviews ${ }^{11}$. This study concluded that the adherence of Chinese publications to the PRISMA recommendations was poor in the studies published up to $2009^{11}$. The authors of this study reinforced that the use of PRISMA recommendations can improve the quality of presentation of systematic reviews. In addition, there are no similar studies that had evaluated the reporting of systematic reviews published in Portuguese. Therefore, the aim of this study was to analyse the reporting of systematic reviews in physical therapy published in Portuguese using the PRISMA Statement. It is important to highlight that the actual analysis involve manuscripts published prior to the publication of PRISMA Statement, and therefore, these studies could not benefit from this guidelines.

\section{Method : :}

This is a bibliometric analysis of systematic reviews and/or meta-analysis related to physical therapy interventions published in Portuguese. Eligible reviews were retrieved from Physiotherapy Evidence Database (PEDro). PEDro was chosen for this study as it is the most comprehensive database in indexing studies related to effects of physical therapy interventions and because PEDro is freely available on the internet (www.pedro.org.au) ${ }^{12,13}$.

All systematic reviews published in Portuguese indexed on PEDro up to August 2011 were included. The search was performed using the "advanced search" option of the database, in which we typed the search term 'Portuguese' and limited the results for systematic reviews only.

Six previously trained raters for the use of the PRISMA checklist participated of the analysis of the eligible systematic 
reviews. Each article had been randomly allocated for two of five team of raters. These ratings were performed independently. In the case of disagreement between raters, a final arbitration was performed by a sixth, more experienced rater. The instrument used by the raters in the analyses of the eligible systematic review was the PRISMA checklist. The 27 items evaluated by this checklist are described in Appendix 1.

All systematic reviews were also classified according to the subdisciplines standardized by the PEDro database. For each item of the checklist, it was established to consider as satisfied only those that fully contemplated recommendations from the PRISMA Statement, being rated as 'yes'. When the rater considered the description of the item incomplete, inexistent or doubtful, the item was rated as 'no'. Such dichotomous criteria of rating were chosen to avoid bias due to different interpretation of the information from the raters. The ratings were organized in independent forms by the raters and were collated in a single document for further consensus if needed. The satisfied items were then summed in a score ranging from zero (no item satisfied) and 27 (all the items satisfied). Moreover, we summed the number of articles that contemplated each one of the checklist items (this value ranged from zero to 37 articles). We also performed frequency distribution analysis of the PRISMA total score by year of publication.

\section{Results $: \because$.}

Our search retrieved 41 systematic reviews; however four articles were excluded because they were not published in Portuguese (two were published in English and two in Italian). Of the 37 eligible studies included, the subdisciplines musculoskeletal and cardiothoracics showed the larger number of systematic reviews. In contrast, no systematic reviews in sports physical therapy were found (Table 1). The analysis of

Table 1. Classification of articles by subdiscipline.

\begin{tabular}{lc}
\hline Subdiscipline & Article $(\mathrm{n})$ \\
\hline 1. Musculoskeletal & 8 \\
\hline 2. Orthopedics & 4 \\
\hline 3. Cardiothoracics & 8 \\
\hline 4. Gerontology & 6 \\
\hline 5. Neurology & 5 \\
\hline 6. Ergonomics and occupational health & 1 \\
\hline 7. Continence and women's health & 1 \\
\hline 8. Pediatrics & 1 \\
\hline 9. Sports & 0 \\
\hline 10. Other & 3 \\
\hline Total & 37 \\
\hline
\end{tabular}

the individual articles, according to the items of the PRISMA checklist can be observed in Table 2.

In the analysis of the total number of items satisfied by year of publication, we observed that, on average, less than a half of the items from the PRISMA Statement were satisfied. Moreover, our data reveal that there was no improvement on the quality of reporting over time (Figure 1). The proportion of items satisfying the recommendations of PRISMA was $29.83 \%$.

In the classification by category, the most satisfied items are the ones related to introduction and discussion sections. On the other hand, most of the items that compose the methods and results sections were not satisfied. The items 5 and 15 (Methods) have not been satisfied in none of the 37 eligible articles while the items 14 (Methods), 21, 22, and 23 (Results) were satisfied in just few studies (Figure 2).

\section{Discussion $: \because$.}

Our results indicate that the adherence to the PRISMA statement recommendations ${ }^{8}$ for most of systematic reviews published in Portuguese in the field of physical therapy was lower than $30 \%$. We also observed a large variability in the fulfillment of the PRISMA items by year of publication; which shows a great potential for improvement in the reporting of systematic reviews published in Portuguese in the future. In spite of the low adeherence to the recommendations, it is important to point out that such results do not mean that the methodological quality of these reviews are low, since PRISMA was not developed for such purpose. The adequate tool for measuring the quality of the systematic reviews is called AMSTAR (Assessment of Multiple Systematic Reviews) ${ }^{14}$.

Considering that systematic reviews are probably the most important type of study to guide the clinical decision in physical therapy, the number of systematic reviews published in Portuguese is still very low if compared to the 3,057 reviews registered in PEDro $^{1}$ database, which equals to only $1.21 \%$ of all available reviews. This number indicates a gap that should be filled in order to help a large number of Portuguese-speaking physical therapists that could benefit with a higher number of systematic reviews published in Portuguese.

The occurrence of a large number of systematic reviews in the subdisciplines musculoskeletal and cardiothoracics in Portuguese analyzed in the present study followed the same trend of distribution presented in other languages. These subdisciplines are also the most prevalent among the 19,729 studies indexed on PEDro ${ }^{1}$. This large number of systematic reviews in the subdisciplines of musculoskeletal and cardiothoracics 
ultimately reflects the areas with a largest number of professionals working in these areas.

The first systematic review in Portuguese was published in 2003, three years after the development of the QUORUM recommendations ${ }^{7,15}$, and therefore this guidelines seems to have not influenced our results. Similarly the use of PRISMA was not observed in most of the eligible articles, which might mean that there was a small influence of these guidelines in the current systematic reviews published in Portuguese.

The 27 items of the PRISMA checklist had not been fulfilled consistently, and some items were satisfied in most of the eligible reviews ( for example reaching $100 \%$ for the item 3 ). On the other hand, items 5 and 15 had not been satisfied in none of the eligible reviews. Item 5 refers to the international registration of systematic review. In a study developed with the same purpose

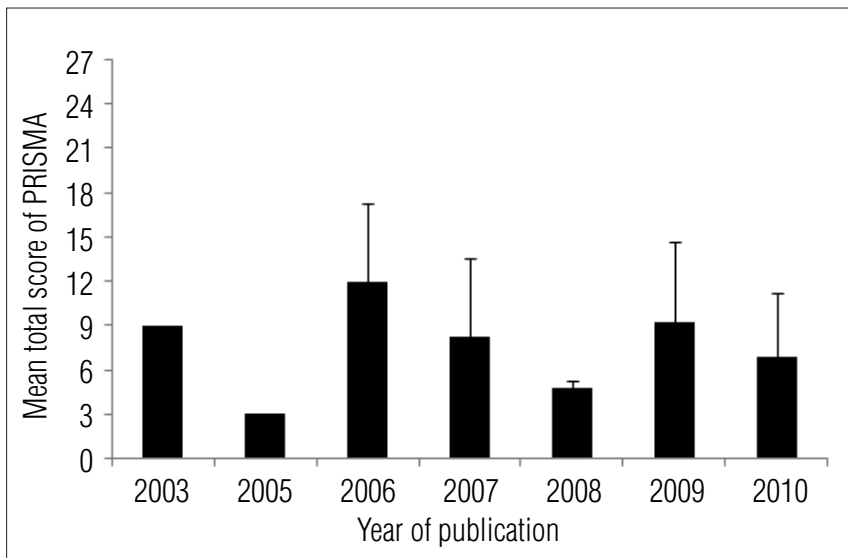

There was only one systematic review published in 2003 and 2005, so there is no presentation of standard deviation for these periods of time.

Figure 1. Mean total score (standard deviation) of PRISMA recommendations per year. of our study for Chinese reviews ${ }^{11}$, the authors reported that none of the articles analyzed by them quoted the registration number, as well as the reviews published in Portuguese. It is known the problems of selection bias (i.e. publishing only positive results) of systematic reviews in international journals. The registration of reviews favors the good practice and transparency of the process of review and publication ${ }^{16}$. Considering this, the practice of registration must be encouraged, although there are few sites available for such procedure (see http://www.ncddr.org/cgi-bin/ systematicreview_submit.cgi, for registration).

Item 15 concerns to the risk of bias of results, which adherence was null in the present study. In the study of Ma et al. ${ }^{11}, 53 \%$ of the Chinese articles satisfied this item related to the risk of bias. The items that were attended by a larger number of authors in our study (3 and 26) corresponded to those items of PRISMA whose criteria of analyses are more subjective. Item 3 refers to the rationale of the study, and the 26 refers to the general interpretation of the results, in other words, to the conclusions of the study. Most part of the other items of the PRISMA recommendations requires a direct answer. These items were able to be more clearly evaluated in the present study, since, for the analysis of the reviews; it was enough to search in the text if the information was available or not (for example, if the title indicates the study as a systematic review - item 1).

It needs to be highlighted that, in the study of Ma et al. ${ }^{11}$, none of the articles analyzed in Chinese showed a structured abstract and a summary of the main results in the discussion, items contemplated by 40 and $55 \%$ of the articles in Portuguese, respectively. The structure of writing of the abstracts seem to be critically dependent on the "instructions to the authors" section of the journals rather than from the knowledge of the author. The publication rules of some scientific journals

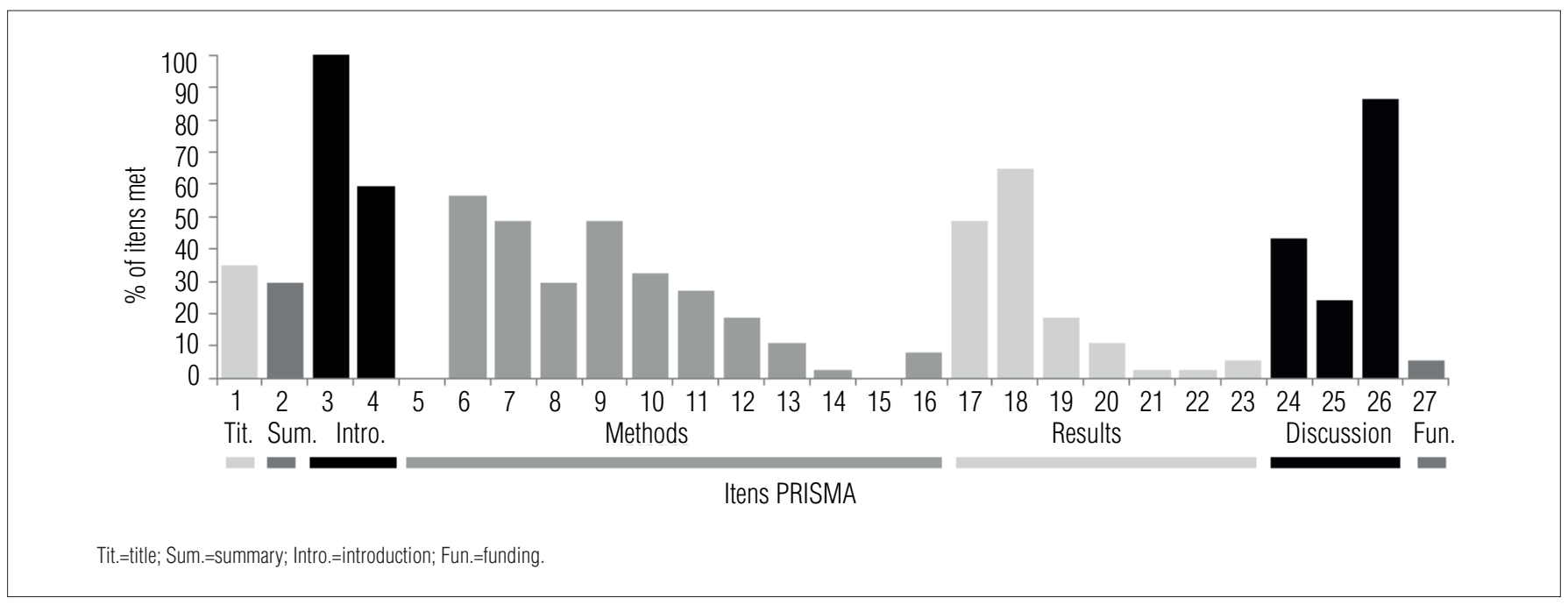

Figure 2. Percentage of items met in each section. 
in Portuguese language require a different manuscript format from that recommended by the check list of PRISMA, which suggests a structured format. Knowing this, in the present study it was considered as fulfilled the item that contemplated all the aspects indicated in PRISMA recommendations, even if the abstract was not structured, however, the same criteria might not have been observed by Ma et al. ${ }^{11}$.

Most of the systematic reviews evaluated in this study did not satisfied to the criteria of the PRISMA checklist. This results does not necessarily indicate the non-observance of the item by the authors during the execution of their study, but, the absence of a clear reporting. The suggestion that the authors must use the PRISMA statement while writing their reviews can avoid this problem in the future.

The aim of the PRISMA Statement is to allow authors to perform a verification of the items that compose it before the submission of articles of systematic review. The results from this study suggest that the adherence of the authors to PRISMA recommendations is low, possibly because it is still new. This adherence could improve the reporting of future systematic reviews.

An analysis of journals related to free access Pediatrics ${ }^{17}$, showed that $19.5 \%$ of 41 the journals had the indication to use the PRISMA (or QUORUM) in the instruction to authors section. It is possible that the suggestion of such recommendations by the editorial board of the journals published in Portuguese, together with the other guidelines for authors, is likely to increase the reporting of systematic reviews published in Portuguese ${ }^{6}$.

A possible limitation of this study would be that some of the articles analyzed were published prior to dissemination of the PRISMA Statement ${ }^{8}$. On the other hand, all eligible reviews were published after the publication of the QUOROM ${ }^{15}$. It is important to note that even if the QUOROM recommendations were used in this study, the results would be very similar. This fact can be inferred by Figure 2, which shows that the reporting of the reviews did not improve over time.

We concluded that most of the authors did not adhere to the criteria recommended by the PRISMA recommendations. Our results may serve as an alert to the scientific community that aims to publish systematic reviews in Portuguese, encouraging future systematic reviews to be reported more clearly and transparently. The implementation of these recommendations requires extensive endorsement by Portuguese-written journals. We also suggest extensive training of the use of these recommendations by journal editors, reviewers and authors. Certainly this is not a simple task, but this can improve the reporting quality of systematic reviews in Portuguese language.

\section{References: : :}

1. PEDro. PEDro access statistics, 2011. Accessed 25/07, 2011. Available from: www.pedro.org.au.

2. Sherrington C, Herbert RD, Maher CG, Moseley AM. PEDro. A database of randomized trials and systematic reviews in physiotherapy. Man Ther. 2000;5(4): 223-6.

3. Shiwa SR, Costa LOP, Moser ADL, Aguiar IC, Oliveira LVF. PEDro: A base de dados de evidências em fisioterapia. Fisioter Mov. 2011;24(3):523-33.

4. Herbert R, Jamtvedt G, Mead J, Hagen KB. Practical Evidence-Based Physiotherapy ed. London: Elsevier's Health Sciences; 2005.

5. Grobbee DE, Hoes AW. Clinical Epidemiology. Principles, methods and applications for clinical researched. Sudbury, Massachusetts: Jones and Bartlett Publishers; 2009

6. Costa LOP, Maher CG, Lopes AD, de Noronha MA, Costa LCM. Transparent reporting of studies relevant to physical therapy practice. Rev Bras Fisioter. 2011;15(4):267-71.

7. Clarke M. The QUORUM statement. Lancet. 2000;355:756-7.

8. Liberati A, Altman DG, Tetzlaff J, Mulrow C, Gotzsche PC, loannidis JPA, et al. The PRISMA statement for reporting systematic reviews and meta-analyses of studies that evaluate health care interventions: explanation and elaboration. Ann Intern Med. 2009;151(4):W65-94.

9. Liberati A, Altman DG, Tetzlaff J, Mulrow C, Gotzsche PC, loannidis JP, et al. The PRISMA statement for reporting systematic reviews and meta-analyses of studies that evaluate health care interventions: explanation and elaboration. PLoS Med. 2009;6(7):e1000100.

10. Tricco AC, Straus SE, Moher D. How can we improve the interpretation of systematic reviews? BMC Med. 2011;9:31.

11. Ma B, Guo J, Qi G, Li H, Peng J, Zhang Y, et al. Epidemiology, quality and reporting characteristics of systematic reviews of traditional Chinese medicine interventions published in Chinese journals. PLoS One. 2011;6(5):e20185.

12. Michaleff ZA, Costa LOP, Moseley AM, Maher CG, Elkins M, Herbert RD, et al. CENTRAL, PEDro,
PubMed, and EMBASE are the most comprehensive databases indexing randomized controlled trials of physical therapy interventions. Phys Ther. 2011;91(2):190-7.

13. Moseley AM, Sherrington C, Elkins MR, Herbert RD, Maher CG. Indexing of randomised controlled trials of physiotherapy interventions: a comparison of AMED, CENTRAL, CINAHL, EMBASE, Hooked on Evidence, PEDro, PsycINF0 and PubMed. Physiotherapy. 2009;95(3): $151-6$.

14. Shea BJ, Grimshaw JM, Wells GA, Boers M, Andersson N, Hamel C, et al. Development of AMSTAR: a measurement tool to assess the methodological quality of systematic reviews. BMC Med Res Methodol. 2007;7:10

15. Moher D, Cook DJ, Eastwood S, Olkin I, Rennie D, Stroup DF. Improving the quality of reports of meta-analyses of randomised controlled trials: the QUOROM statement. Quality of Reporting of Meta-analyses. Lancet. 1999;354(9193):1896-900.

16. Booth $A$, Clarke M, Ghersi D, Moher D, Petticrew M, Stewart L. An international registry of systematic-review protocols. Lancet. 2011;377(9760):108-9.

17. Meerpohl JJ, Wolff RF, Antes G, von Elm E. Are pediatric Open Access journals promoting good publication practice? An analysis of author instructions. BMC Pediatr. 2011;11:27.

18. Arantes NF, Vaz DV, Mancini MC, Pereira MSDC, Pinto FP, Pinto TPS. Efeitos da estimulação elétrica funcional nos músculos do punho e dedos em indivíduos hemiparéticos: uma revisão sistemática da literatura. Rev Bras Fisioter. 2007;11(6):419-27.

19. Arantes PMM, Alencar MA, Dias RC, Dias JMD, Pereira LSM. Atuacão da fisioterapia na síndrome de fragilidade: revisão sistemática. Rev Bras Fisioter. 2009;13(5):365-75.

20. de Araujo SR, de Mello MT, Leite JR. Transtornos de ansiedade e exercício fisico. Rev Bras Psiquiatr. 2007;29(2):164-71

21. Silva Borges CA, Castao KC, Souto PA, Borges Zan T, Pompeu JE, Fukuda TY. Effect of resisted exercise on muscular strength, spasticity and functionality in chronic hemiparetic subjects: a systematic review. J Appl Res. 2009;9(4):147-58. 
22. Brol AM, Bortoloto F, Magagnin NMS. Tratamento de restrição e indução do movimento na reabilitação funcional de pacientes pós acidente vascular encefálico: uma revisão bibliográfica. Fisioter Mov. 2009;22(4):497-509.

23. de Melo Coelho FG, Santos-Galduroz RF, Gobbi S, Stella F. Atividade fisica sistematizada e desempenho cognitivo em idosos com demência de Alzheimer: uma revisão sistemática. Rev Bras Psiquiatr. 2009;31(2):163-70

24. Comaru T, Silva E. Segurança e eficácia da fisioterapia respiratória em recém-nascidos: uma revisão da literatura. Fisioter Pesqui. 2007;14(2):91-7.

25. Coury HJCG, Moreira RFC, Dias NB. Efetividade do exercicio físico em ambiente ocupacional para controle da dor cervical, lombar e do ombro: uma revisão sistemática. Rev Bras Fisioter. 2009;13(6):461-79

26. Fernandes KR, Oliveira P, Bertolo D, Andrade GN, Matsuda NY, Renno ACM. Efeitos dos recursos eletrofisicos na osteoporose: uma revisão da literatura. Fisioter Mov. 2010;23(2):271-81.

27. Ferreira MC, Penido H, Aun A, Ferreira P, Ferreira ML, Oliveira VC. Eficácia dos exercícios de controle motor na dor lombopélvica: uma revisão sistemática. Fisioter Pesqui. 2009;16(4):374-9.

28. Ike D, Di Lorenzo VAP, Costa D, Jamami M. Drenagem postural: prática e evidência. Fisioter Mov. 2009;22(1):11-7.

29. Jacques KC, Drumond NR, Andrade SAF, Chaves Junior IP, Toffol WC. Eficácia da hidroterapia em crianças com encefalopatia crônica não progressiva da infância: revisão sistemática. Fisioter Mov. 2010;23(1):53-61.

30. Locatelli EC, Pelizzari S, Scapini KB, Leguisamo CP, da Silva AB. Exercícios físicos na doença arterial obstrutiva periférica. J Vasc Bras. 2009;8(3):247-54.

31. Maluf SA, Moreno BCD, Alfredo PP, Marques AP. Exercicios terapêuticos nas desordens temporomandibulares: uma revisão de literatura. Fisioter Pesqui. 2008;15(4):408-15.

32. Mann L, Kleinpaul JF, Teixeira CS, Konopka CK. Dor lombo-pélvica e exercício fisico durante a gestação. Fisioter Mov. 2008;21(2):99-105

33. Miculis CP, Pereira EF, Cieslak F, Hernandez SG, Góes SM, Israel VL. Efeito do exercício fisico em condições osteomioarticulares: revisão de literatura. Fisioter Mov. 2009;22:575-84.

34. Moraes HS, Deslandes A, Ferreira C, Pompeu F, Ribeiro P, Laks J. 0 exercício físico no tratamento da depressão em idosos: revisao sistemática. Rev Psiquiatr Rio Gd Sul. 2007;29(1):70-9.

35. Nasrala MLS, Santos VM, Nasrala Neto E, Arruda e Sá MTM, Miranda ALF, Proceski LRC. Tilt training como tratamento da síncope. Fisioter Mov. 2007;20(2):73-81.

36. Passos GS, Tufik S, Santana MG, Poyares D, Mello MT. Tratamento não farmacológico para a insônia crônica. Rev Bras Psiquiatr. 2007;29(3):279-82.

37. Queiroz ACC, Kanegusuku H, Forjaz CLM. Efeitos do treinamento resistido sobre a pressão arterial de idosos: revisão. Arq Bras Cardiol. 2010;95(1):135-40.

38. Renault JA, Costa-Val R, Rossetti MB. Respiratory physiotherapy in the pulmonary dysfunction after cardiac surgery. Rev Bras Cir Cardiovasc. 2008;23(4):562-9.
39. Ricci NA, Coimbra IB. Exercício físico como tratamento na osteoartrite de quadril: uma revisão de ensaios clínicos aleatórios controlados. Rev Bras Reumatol. 2006;46(4):273-80.

40. Ricci NA, Dias CNK, Driusso P. A utilização dos recursos eletrotermofototerapêuticos no tratamento da síndrome da fibromialgia: uma revisão sistemática. Rev Bras Fisioter. 2010;14(1):1-9.

41. Sabino GS, de Souza MVS, de Resende MA. Estimulação eletrica nervosa transcutanea no pósoperatório de cirurgia torácica ou abdominal. Fisioter Mov. 2006;19(1):59-71.

42. Salmela LFT, Macedo BG, Aguiar CM, Bahia LA. 0 impacto da movimentação passiva contínua no tratamento de pacientes submetidos a artroplastia total de joelho. Acta Fisiatric. 2003;10(1): $21-7$.

43. Santos ML, Borges GF. Exercício fisico no tratamento e prevenção de idosos com osteoporose: uma revisão sistemática. Fisioter Mov. 2010;23(2):289-99.

44. Severo VG, Rech VV. Reabilitação pulmonar: treinamento de membros superiores em pacientes com DPOC; uma revisão. Fisioter Pesqui. 2006;13(1):44-52.

45. Silva DRF, Reis PED, Gomes IP, Funghetto SS, de Leon CGR. Non pharmacological interventions for chemotherapy induced nauseas and vomits: integrative review. Online Braz J Nursing. 2009;8(1):Epub.

46. Silva LA, Tamashiro V, Assis RD. Terapia por contensão induzida: revisão de ensaios clinicos. Fisioter Mov. 2010;23(1):153-9.

47. Cardoso de Souza M, Trajano Jorge R, Jones A, Lombardi Júnior I, Natour J. Progressive resistance training in patients with shoulder impingement syndrome: literature review. Reumatismo. 2009;61(2):84-9.

48. Teixeira LJ, Machado JNP. Manobras para o tratamento da vertigem posicional paroxistica benigna: revisão sistemática da literatura. Rev Bras Otorrinolaringol. 2006;72(1): 130-9.

49. Teixeira PC, da Costa RF, Matsudo SMM, Cordás TA. A prática de exercícios físicos em pacientes com transtornos alimentares. Rev Psiquiatr Clin (São Paulo). 2009;36(4):145-52.

50. Sarmento Tenorio LH, Jaguaribe de Lima AM, Brasileiro-Santos MS. Intervenção da fisioterapia respiratória na função pulmonar de indivíduos obesos submetidos a cirurgia bariátrica: uma revisão. Rev Port Pneumol. 2010;16(2):307-14

51. Vieira LA, Malta RD, Sabino GS. Biofeedback eletromiográfico (biofeedback/EMG) no pósoperatorio de joelho. Fisioter Mov. 2007;20(3):107-13.

52. Vital TM, Hernandez SSS, Gobbi S, Costa JLR, Stella F. Atividade física sistematizada e sintomas de depressão na demência de Alzheimer: uma revisão sistemática. J Psiquiatr. 2010;59(1): $58-64$.

53. Bueno VC, Lombardi Júnior I, Medeiros WM, Azevedo MMA, Len CA, Terreri MTRA, et al Reabilitação em artrite idiopatica juvenil. Rev Bras Reumatol. 2007;47(3):197-203.

54. Ribeiro FR, Leite ML, Silva FS, Sousa OS. Exercicio fisico no tratamento da espondilite anquilosante uma revisao sistematica. Acta Reumatol Port. 2007:32(2):129-37. 
Appendix 1. PRISMA Statement ${ }^{8}$.

\begin{tabular}{|c|c|c|}
\hline Item & Section/Topic & Description \\
\hline 1 & Title & Identify the report as a systematic review, meta-analysis, or both. \\
\hline 2 & Structured abract & $\begin{array}{l}\text { Provide a structured summary including, as applicable: background; objectives; data sources; study eligibility criteria, par- } \\
\text { ticipants, and interventions; study appraisal and synthesis methods; results; limitations; conclusions and implications of key } \\
\text { findings; systematic review registration number.. }\end{array}$ \\
\hline & Introduction & \\
\hline 3 & Rationale & Describe the rationale for the review in the context of what is already known. \\
\hline 4 & Objectives & $\begin{array}{l}\text { Provide an explicit statement of questions being addressed with reference to participants, interventions, comparisons, out- } \\
\text { comes, and study design (PICOS). }\end{array}$ \\
\hline & Methods & \\
\hline 5 & Protocol and registration & $\begin{array}{l}\text { Indicate if a review protocol exists, if and where it can be accessed (e.g., Web address), and, if available, provide registration } \\
\text { information including registration number. }\end{array}$ \\
\hline 6 & Eligibility criteria & $\begin{array}{l}\text { Specify study characteristics (e.g., PICOS, length of follow-up) and report characteristics (e.g., years considered, language, } \\
\text { publication status) used as criteria for eligibility, giving rationale. }\end{array}$ \\
\hline 7 & Information sources & $\begin{array}{l}\text { Describe all information sources (e.g., databases with dates of coverage, contact with study authors to identify additional } \\
\text { studies) in the search and date last searched. }\end{array}$ \\
\hline 8 & Search & Present full electronic search strategy for at least one database, including any limits used, such that it could be repeated. \\
\hline 9 & Study selection & $\begin{array}{l}\text { State the process for selecting studies (i.e., screening, eligibility, included in systematic review, and, if applicable, included in } \\
\text { the meta-analysis). }\end{array}$ \\
\hline 10 & Data collection process & $\begin{array}{l}\text { Describe method of data extraction from reports (e.g., piloted forms, independently, in duplicate) and any processes for } \\
\text { obtaining and confirming data from investigators. }\end{array}$ \\
\hline 11 & Data items & $\begin{array}{l}\text { List and define all variables for which data were sought (e.g., PICOS, funding sources) and any assumptions and simplifica- } \\
\text { tions made. }\end{array}$ \\
\hline 12 & $\begin{array}{l}\text { Risk of bias in individual } \\
\text { studies }\end{array}$ & $\begin{array}{l}\text { Describe methods used for assessing risk of bias of individual studies (including specification of whether this was done at the } \\
\text { study or outcome level), and how this information is to be used in any data synthesis. }\end{array}$ \\
\hline 13 & Summary measures & State the principal summary measures (e.g., risk ratio, difference in means). \\
\hline 14 & Synthesis of results & $\begin{array}{l}\text { Describe the methods of handling data and combining results of studies, if done, including measures of consistency (e.g., }\left.\right|^{2} \text { ) } \\
\text { for each meta-analysis. }\end{array}$ \\
\hline 15 & $\begin{array}{l}\text { Risk of bias across } \\
\text { studies }\end{array}$ & $\begin{array}{l}\text { Specify any assessment of risk of bias that may affect the cumulative evidence (e.g., publication bias, selective reporting } \\
\text { within studies). }\end{array}$ \\
\hline 16 & Additional analyses & $\begin{array}{l}\text { Describe methods of additional analyses (e.g., sensitivity or subgroup analyses, meta-regression), if done, indicating which } \\
\text { were pre-specified. }\end{array}$ \\
\hline & Results & \\
\hline 17 & Study selection & $\begin{array}{l}\text { Give numbers of studies screened, assessed for eligibility, and included in the review, with reasons for exclusions at each } \\
\text { stage, ideally with a flow diagram. }\end{array}$ \\
\hline 18 & Study characteristics & $\begin{array}{l}\text { For each study, present characteristics for which data were extracted (e.g., study size, PICOS, follow-up period) and provide } \\
\text { the citations. }\end{array}$ \\
\hline 19 & Risk of bias within studies & Present data on risk of bias of each study and, if available, any outcome level assessment (see item 12). \\
\hline 20 & $\begin{array}{l}\text { Results of individual } \\
\text { studies }\end{array}$ & $\begin{array}{l}\text { For all outcomes considered (benefits or harms), present, for each study: (a) simple summary data for each intervention group } \\
\text { (b) effect estimates and confidence intervals, ideally with a forest plot. }\end{array}$ \\
\hline 21 & Synthesis of results & Present results of each meta-analysis done, including confidence intervals and measures of consistency. \\
\hline 22 & $\begin{array}{l}\text { Risk of bias across } \\
\text { studies }\end{array}$ & Present results of any assessment of risk of bias across studies (see Item 15). \\
\hline 23 & $\begin{array}{l}\text { Additional analysis } \\
\text { Discussion }\end{array}$ & Give results of additional analyses, if done (e.g., sensitivity or subgroup analyses, meta-regression [see Item 16]). \\
\hline 24 & Summary of evidence & $\begin{array}{l}\text { Summarize the main findings including the strength of evidence for each main outcome; consider their relevance to key } \\
\text { groups (e.g., healthcare providers, users, and policy makers). }\end{array}$ \\
\hline 25 & Limitations & $\begin{array}{l}\text { Discuss limitations at study and outcome level (e.g., risk of bias), and at review-level (e.g., incomplete retrieval of identified } \\
\text { research, reporting bias). }\end{array}$ \\
\hline 26 & Conclusions & Provide a general interpretation of the results in the context of other evidence, and implications for future research. \\
\hline 27 & Funding & $\begin{array}{l}\text { Describe sources of funding for the systematic review and other support (e.g., supply of data); role of funders for the system- } \\
\text { atic review. }\end{array}$ \\
\hline
\end{tabular}

From: Moher D, Liberati A, Tetzlaff J, Altman DG, The PRISMA Group (2009). Preferred Reporting Items for Systematic Reviews and Meta-Analyses: The PRISMA Statement. PLoS Med 6(6): e1000097. doi:10.1371/journal.pmed1000097 